\title{
Combined effects of dietary restrictions and physical activity on amino acid utilization in rats
}

\author{
I. A. M. MAAS, V. V. A. M. SCHREURS, P. J. M. WEIJS, M. FRINGS, \\ B. A. C. VAN ACKER, H. A. BOEKHOLT \& R. E. KOOPMANSCHAP
}

Department of Human and Animal Physiology, Wageningen Agricultural University, Haarweg 10, NL-6709 PJ Wageningen, Netherlands

Received 26 March 1988; accepted 3 August 1989

\begin{abstract}
Female Wistar rats kept on protein or energy restricted diets or normal unrestricted diets for 1 or 7 weeks, were subjected to intensive treadmill exercise. Injections with $\mathrm{L}-\left[\mathrm{U}-{ }^{14} \mathrm{C}\right]-$ tyrosine, $21 \mathrm{~h}$ after the exercise, were used to trace amino acid oxidation and incorporation in tissue proteins of liver, kidneys, M. soleus and muscles of the upper and lower foreleg. Protein restriction decreased tyrosine oxidation (expressed as percentage of the injected dose), with scarce effect on the incorporation in tissue proteins. Apparently the reduced protein supply was not a real restriction. Energy restriction increased tyrosine oxidation and decreased incorporation levels significantly. With energy restriction, amino acids are probably used to compensate for the lack of energy, resulting in a secondary protein restriction. Treadmill running, in combination with dietary protein and energy restriction, increased tyrosine incorporation in most of the examined tissues. The results indicate that, under nutritionally less favourable circumstances (especially a low-energy normal-protein diet), a single bout of exercise can stimulate protein synthesis, even until $21 \mathrm{~h}$ after performance. The rise in tyrosine incorporation was, on all diets, highest for the muscles of the foreleg. Recovery from muscle degeneration, resulting from treadmill exercise, might account for the increased protein synthesis.
\end{abstract}

Keywords: amino acid incorporation, amino acid oxidation, energy restriction, protein restriction, physical activity, treadmill

\section{Introduction}

On whole body level, the free amino acids are mainly used for protein synthesis and energy metabolism. Concerning protein metabolism, amino acids are distributed over different tissues according to the tissue requirements. Amino acids taking part in energy metabolism are first decarboxylated and then either completely oxidized or transformed and stored as fat or glycogen. Factors such as composition of the diet and physical activity determine the priorities of the different metabolic routes. On whole body level, a low-protein diet initially tends to reduce amino acid oxidation (Harper \& Benjamin, 1984; Sketcher et al., 1973, Young et al., 1985). Subse- 
quently a repartitioning of amino acids over the different tissues may take place (Booth et al., 1982; Millward et al., 1976; Waterlow et al., 1978). Restriction of energy intake may result in an increase in amino acid oxidation (Sketcher et al., 1973) and elicits adaptations in protein synthesis on tissue level because of a (secondary) decrease in amino acid supply (Garlick et al., 1975; Millward et al., 1976; Waterlow et al., 1978; Young et al., 1983).

The physiological role of the different tissues for maintaining vital functions and the degree of the dietary restriction determine the nature of the effect on particular tissues. Under normal conditions, muscle and liver tissue have low and high priorities for protein synthesis, respectively (Garlick et al., 1975; Millward et al., 1976; Waterlow et al., 1978).

In normal, well-fed animals, during and immediately after intensive physical activity the $\mathrm{N}$-balance of the body tends to become negative; protein synthesis being suppressed, protein breakdown and amino acid oxidation being increased (Booth et al., 1982; Kuipers et al., 1985; Rennie et al., 1981; Schreurs et al., 1987; Vikho et al., 1978; Viru, 1987). Compensation for these nitrogen losses may take hours to days and is marked by significantly higher levels of protein synthesis and decreased amino acid oxidation (Booth et al., 1982; Viru, 1987). The kind of physical activity, the condition of the animal and nutritional state will determine the magnitude of the effect.

The aim of this study was to compare the post-exercise effect of treadmill running on the metabolic fate of amino acids, at different levels of protein or energy intake.

\section{Materials and methods}

Fourty-eight female Wistar rats (6 months, ca $250 \mathrm{~g}$ ) were randomly alloted to one of the four following diets: (1) control diet (C); (2) low-protein diet (LP); (3) lowenergy diet (LE); (4) low-energy low-protein diet (LEP). Diets C and LP were available ad libitum. Protein-restricted diets LP and LEP contained only half the amount of protein on a weight to weight basis. Energy-restricted diets LE and LEP were given in amounts equal to amounts eaten by the normal energy groups. Energy intake restriction was achieved by reducing the energy density of the feed by $30 \%$, without reducing the protein content.

The animals were subjected to a dietary period of either 1 week or 7 weeks. They were weighed three times a week. At the end of a dietary period, two days were spent getting half of the animals (the exercising group) accustomed to treadmill exercise. On the last day, the animals had to run $130 \mathrm{~min}$ with a speed of $9 \mathrm{~m} \mathrm{~min}^{-1}$ (without real training the maximal achievement for these animals). The nonexercising group remained in their cages during the treadmill running.

All animals received an intraperitoneal injection of $185 \mathrm{kBq} \mathrm{L}-\left[\mathrm{U}-{ }^{14} \mathrm{C}\right]-$ tyrosine, $21 \mathrm{~h}$ after the treadmill activity, in order to determine amino acid utilization as follows. Air from a constantly ventilated cage was bubbled through a $\mathrm{KOH}$-solution in which the expired $\mathrm{CO}_{2}$ was trapped and the cumulated amount of ${ }^{14} \mathrm{CO}_{2}(\mathrm{dpm})$ after $4 \mathrm{~h}$ was expressed as a percentage of the injected dose. Specific activity (dpm $\mathrm{g}^{-1}$ protein) of the tissue proteins (liver, kidneys, M. soleus and foreleg) was deter- 
mined after isolation with SDS gel filtration (modified from Schreurs et al., 1983). Specific activity (SA) was corrected for injected dose of tyrosine per bodyweight, giving a new variable, the corrected specific activity (SA $\left.{ }^{1}\right)$.

$\mathrm{SA}^{1}=\mathrm{SA} \times($ bodyweight $/$ dose $) \times($ mean dose $/$ mean bodyweight $)$

Higher $\mathrm{SA}^{1}$-values indicate a higher rate of protein synthesis.

Statistical analysis was performed by means of analysis of variance. Differences in oxidation data and $\mathrm{SA}^{1}$-values between diet-control groups or exercising/nonexercising groups (within diet groups) were tested for significance $(P<0.05)$ with Student's t-test.

\section{Results}

Actual energy intake relative to bodyweight was $843 \mathrm{~kJ} \mathrm{~kg}^{-1} \mathrm{~d}^{-1}$ for the control group and 855, 679 and $634 \mathrm{~kJ} \mathrm{~kg}^{-1} \mathrm{~d}^{-1}$ for the LP, LE and LEP groups, respectively. Actual energy intake restriction was only 20 (LE) to 25 (LEP) \% of energy intake of C. Actual protein relative to bodyweight was $58 \mathrm{~g} \mathrm{~kg}^{-1} \mathrm{~d}^{-1}$ for $\mathrm{C}$ and 29 , 58 and $29 \mathrm{~g} \mathrm{~kg}^{-1} \mathrm{~d}^{-1}$ for the LP, LE and LEP groups, respectively.

In equicaloric diets, the bodyweight of adult rats was hardly dependent on protein content. On energy intake restriction for 7 weeks, bodyweight decreased by $15 \%$.

Results of amino acid utilization on whole body level (Table 1) showed a decrease of amino acid oxidation when daily protein intake decreased $(P<0.001)$. This effect was most clearly seen in the one week trial. A one week protein restriction scarcely influenced incorporation of tyrosine (Table 2). After 7 weeks, SA ${ }^{1}$ of liver and kidneys seemed to be increased in contrast to the $\mathrm{SA}^{1}$ of $\mathrm{M}$. soleus and foreleg muscles, but insignificantly.

Energy restriction increased oxidation levels $(P<0.001)$. After one week the $\mathrm{SA}^{1}$ of liver, foreleg and $M$. soleus increased $(P<0.001)$ and of kidneys decreased $(P<0.05)$. Incorporation of tyrosine was lower in all tissues in the 7 week trial (Ta-

Table 1. Tyrosine oxidation in rats on different diets, with or without treadmill activity. Each result is the mean (SD) oxidation for three rats (percentage of injected dose).

\begin{tabular}{llllll}
\hline $\begin{array}{l}\text { Dietary } \\
\text { period } \\
\text { (weeks) }\end{array}$ & $\begin{array}{l}\text { Physical } \\
\text { activity } \\
(+/-)\end{array}$ & C & Dieta & & \\
\cline { 3 - 6 } 1 & & LP & LE & LEP \\
1 & - & $22.6(3.3)^{\mathrm{b}}$ & $10.6(1.4)$ & $29.0(2.8)$ & $23.6(0.2)$ \\
& + & $11.4(2.4)$ & $13.4(0.5)$ & $19.1(4.3$ & $14.0(3.5)$ \\
7 & - & $15.7(2.6)$ & $13.3(1.1)$ & $27.8(1.9)^{*}$ & $27.5(5.5)$ \\
& + & $19.1(2.6)$ & $14.4(3.9)$ & $25.1(6.9)$ & $18.8(5.9)$ \\
\hline
\end{tabular}

a $\mathrm{C}=$ control diet; $\mathrm{LP}=$ low-protein diet; $\mathrm{LE}=$ low-energy diet; $\mathrm{LEP}=$ low-energy, low-protein diet. b Mean (SD) for two rats. 
ble 2), and reached significance in kidneys $(P<0.01)$ and M. soleus $(P<0.05)$. The effect of treadmill activity on tyrosine oxidation $21 \mathrm{~h}$ later (Table 1) was a significant decrease in the one week trial and especially with energy restriction $(P<0.001)$. Compared to the non-exercising groups, $\mathrm{SA}^{1}$ of the exercising groups on protein and especially the energy-restricted diets, is higher in most of the examined tissues (Table 2). This effect was most pronounced for the muscles of the foreleg in the 7 week trial $(P<0.001)$.

\section{Discussion}

First of all we want to make some general remarks concerning the interpretation of the results. Amino acid utilization was studied by tracing labeled tyrosine in expired

Table 2. Corrected specific activities of 4 tissues of rats on different diets, with or without treadmill activity. Each result is the mean (SD) $\mathrm{SA}^{1}$ for three rats (dpm $\mathrm{g}^{-1}$ protein).

\begin{tabular}{|c|c|c|c|c|c|}
\hline \multirow{2}{*}{$\begin{array}{l}\text { Dietary } \\
\text { period } \\
\text { (weeks) }\end{array}$} & \multirow{2}{*}{$\begin{array}{l}\text { Physical } \\
\text { activity } \\
(+/-)\end{array}$} & \multicolumn{4}{|l|}{ Diet $^{a}$} \\
\hline & & $\mathrm{C}$ & LP & LE & LEP \\
\hline \multicolumn{6}{|l|}{ Liver } \\
\hline 1 & $\begin{array}{l}- \\
+\end{array}$ & $\begin{array}{l}466(55)^{b} \\
424(43)\end{array}$ & $\begin{array}{l}497(63) \\
487(3)^{b}\end{array}$ & $\begin{array}{l}687(49) \\
668(59)\end{array}$ & $\begin{array}{l}791(136) \\
836(37)\end{array}$ \\
\hline 7 & $\begin{array}{l}- \\
+\end{array}$ & $\begin{array}{l}443(77) \\
452(37)\end{array}$ & $\begin{array}{l}572(55) \\
665(141)\end{array}$ & $\begin{array}{l}281(21)^{\mathrm{b}} \\
567(36)^{\mathrm{b}}\end{array}$ & $\begin{array}{l}434(89) \\
524(308)\end{array}$ \\
\hline \multicolumn{6}{|l|}{ Kidneys } \\
\hline 1 & $\begin{array}{l}- \\
+\end{array}$ & $\begin{array}{l}997(51)^{b} \\
854(82)\end{array}$ & $\begin{array}{l}930(46) \\
918(149)\end{array}$ & $\begin{array}{l}669(55) \\
905(119)\end{array}$ & $\begin{array}{l}811(181) \\
827(129)\end{array}$ \\
\hline 7 & $\begin{array}{l}- \\
+\end{array}$ & $\begin{array}{l}515(117) \\
518(53)\end{array}$ & $\begin{array}{l}546(94) \\
646(111)\end{array}$ & $\begin{array}{l}347(101)^{\mathrm{b}} \\
481(56)\end{array}$ & $\begin{array}{l}375(54) \\
457(92)\end{array}$ \\
\hline \multicolumn{6}{|c|}{ Muscles of the foreleg } \\
\hline 1 & $\begin{array}{l}- \\
+\end{array}$ & $\begin{array}{l}79(17)^{b} \\
77(9)\end{array}$ & $\begin{array}{l}66(3) \\
72(14)\end{array}$ & $\begin{array}{r}86(6) \\
113(8)\end{array}$ & $\begin{array}{r}99(9) \\
110(6)\end{array}$ \\
\hline 7 & $\begin{array}{l}- \\
+\end{array}$ & $\begin{array}{l}50(2) \\
62(7)\end{array}$ & $\begin{array}{l}43(9) \\
82(9)\end{array}$ & $\begin{array}{l}37(0)^{b} \\
63(5)\end{array}$ & $\begin{array}{l}41(8) \\
59(17)\end{array}$ \\
\hline M. soleu & & & & & \\
\hline 1 & $\begin{array}{l}- \\
+\end{array}$ & $\begin{array}{l}136(19)^{\mathrm{b}} \\
107(12)\end{array}$ & $\begin{array}{l}118(11) \\
103(15)\end{array}$ & $\begin{array}{l}160(4) \\
179(19)\end{array}$ & $\begin{array}{l}171(10) \\
191(13)\end{array}$ \\
\hline 7 & $\begin{array}{l}- \\
+\end{array}$ & $\begin{array}{l}121(6) \\
102(33)\end{array}$ & $\begin{array}{r}98(26) \\
127(29)\end{array}$ & $\begin{array}{r}56(8)^{\mathrm{b}} \\
105(11)\end{array}$ & $\begin{array}{l}95(10) \\
95(17)\end{array}$ \\
\hline
\end{tabular}

a $\mathrm{C}=$ control diet $; \mathrm{LP}=$ low-protein diet; $\mathrm{LE}=$ low-energy diet; LEP = low-energy, low-protein diet.

${ }^{b}$ Mean (SD) for two rats. 
$\mathrm{CO}_{2}$ and in tissue proteins of four tissues. The total amount of label traced in this way accounts for about $20-40 \%$ of the injected dose. Conclusions about changes in amino acid utilization on whole body level can therefore only be made by extrapolation of the results. Also, universally labeled tyrosine was used for practical reasons, implicating a lack of information on changes in the decarboxylation of tyrosine and subsequent transformation into fat or glycogen.

Adult rats could easily cope with a protein restriction upto $50 \%$ for 7 weeks. Bodyweight remained constant and changes in amino acid incorporation were not significant. There was only a tendency towards higher priorities of liver and kidneys when compared to muscle tissue. Amino acid oxidation decreased, probably because supply was no longer exceeding the requirements.

Dietary energy restriction to $70 \%$ posed higher demands on dietary protein to compensate for the arisen lack of fuel. This gave rise to a secundary protein restriction. The low $\mathrm{SA}^{1}$-values and the high oxidation levels after 7 weeks on this diet support this hypothesis.

Compared to non-exercised rats, treadmill running (130 $\left.\mathrm{min}, 9 \mathrm{~m} \mathrm{~min}^{-1}\right)$ increased the level of amino acid incorporation in most of the examined tissues, when measured $21 \mathrm{~h}$ after the activity. This suggests higher levels of protein synthesis at that time. The rise in protein synthesis can be explained in terms of compensation for the losses sustained during treadmill activity. During and after submaximal physical activity, decreased protein synthesis has been often reported (Booth et al., 1982; Rennie et al., 1981; Viru, 1987). Vikho et al. (1978) and Kuipers et al. (1985) also report the existence of small lesions, visible in muscles intensively used during treadmill running.

Recovery, marked by significant increases in protein synthesis, is believed to take place until days after the activity. In our study, observations of the rats made clear that the foreleg is mostly stressed during treadmill running. The $\mathrm{SA}^{1}$-values of this muscle are in keeping with the above-mentioned results.

Physical activity increased protein synthesis more in the diet groups than in the control group. Combination of physical activity with an energy-restricted diet, containing sufficient protein, gave a greater overall increase in incorporation than any other combination of activity and diet, in spite of the high levels of oxidation in the non-exercising groups. Physical activity seems to limit the use of amino acids for energy expenditure in favor of protein synthesis. These results are in line with the hypothesis of Young (1983) that moderate, systemic exercise has a favourable impact on the utilization of dietary protein. Young also concludes from studies with adult obese subjects that, when dietary energy is restricted and protein supply is sufficient, lipid reserves of the body can meet the energy requirements in order to maintain protein synthesis. In our study however, the low-energy normal-protein diet caused low incorporation and high oxidation levels, suggesting protein was used as fuel for energy metabolism in adult non-obese rats. But when this diet was combined with submaximal physical activity, protein synthesis was enhanced, suggesting that in this case lipid reserves of the body instead of dietary protein were possibly used to meet the energy requirements. 


\section{References}

Booth, W. F., W. F. Nicholsen \& P. A. Watson, 1982. Influence of muscle use on protein synthesis and degradation. Exercise and Sports Sciences Reviews 10: 27-48.

Garlick, P. J., D. J. Millward, W. P. T. James \& J. C. Waterlow, 1975. The effect of protein deprivation and starvation on the rate of protein synthesis in tissues of the rat. Biochimica et Biophysica Acta 414: 71-84.

Harper, A. E. \& E. Benjamin, 1984. Relationship between intake and rate of oxidation of leucine and alfa-ketoisocaproate in vivo in the rat. Journal of Nutrition 114: 431-400.

Kuipers, H., J. Drukker, P. M. Frederik, P. Geurten \& G. van Kranenburg, 1985. Muscle degeneration after exercise in rats. International Journal of Sports Medicine 4: 45-51.

Millward, D. J., P. J. Garlick, W. P. T. James, P. M. Sender \& J. C. Waterlow, 1976. Protein turnover. In: D. J. A. Cole, K. N. Borman, P. J. Buttery, D. Lewis, R. J. Neale \& H. Swann (Eds), Protein metabolism and nutrition, p. 49-70. Buttersworth, London.

Rennie, M. J., R. H. T. Edwards, D. Halliday, C. T. M. Davies, D. E. Matthews \& D. J. Millward, 1981. Protein metabolism during exercise. In: J. C. Waterlow \& J. M. L. Stephen (Eds), Nitrogen metabolism in man, p. 509-523. Applied Science Publishers, London.

Schreurs, V. V. A. M., M. van Amstel, F. J. Elbers, E. S. M. Holtslag, N. Vos, H. A. Boekholt \& R. E. Koopmanschap, 1987. Examination of a protein-sparing effect of exogenous leucine during physical activity. Netherlands Journal of Agricultural Science 35: 541-545.

Schreurs, V. V. A. M., H. A. Boekholt \& R. E. Koopmanschap, 1983. Gel filtration in sodium dodecyl sulphate of hydrophobic muscle proteins on Sephacryl S-400 superfine. Journal of Chromatography 254: 203-210.

Sketcher, R. D., E. B. Fern \& W. P. T. James, 1973. The adaptation in muscle oxidation of leucine to dietary protein and energy intake. British Journal of Nutrition 31: 333-342.

Vikho, V., J. Rantamaki \& A. Salminen, 1978. Exhaustive physical exercise and acid hydrolase activity in mouse skeletal muscle. Histochemistry 57: 237-249.

Viru, A., 1987. Mobilisation of structural proteins during exercise. Sports Medicine 4: 95-128.

Waterlow, J. C., P. J. Garlick \& D. J. Millward (Eds), 1978. Protein turnover in mammalian tissues and in the whole body. North Holland Publishing Company, Amsterdam.

Young, V. R., L. L. Moldawer, R. Hoerr \& D. M. Bier, 1985-Mechanisms of adaptation to protein malnutrition. In: K. Blaxter \& J. C. Waterlow (Eds), p. 189-217. John Libbey, London.

Young, V. R., H. N. Munro, D. E. Matthews \& D. M. Bier, 1983. Relationship of energy metabolism to protein metabolism. In: G. Kleinberger \& E. Deutsch (Eds), p. 43-73. Karger, Basel.

This synopsis is based on an undergraduate thesis 'Invloed van ondervoeding en tredmolenactiviteit op het eiwitmetabolisme van de rat' by I. Maas, M. Frings and B. van Acker. Dept of Human and Animal Physiology, Wageningen Agricultural University, Wageningen, 1987, 59 pp., 21 fig., 8 tables, 44 refs., 16 appendices, in Dutch. Available as paper copy (order R095, $f 15$ including postage) at: NARD, c/o Pudoc, P.O. Box 4, 6700 AA Wageningen, Netherlands (telex 45015 bluwg $\mathrm{nl}$ ). 